\title{
PENINGKATAN MUTU PENDIDIKAN KEJURUAN \\ BERORIENTASI PASAR KERJA MELALUI UJI KOMPETENSI KEAHLIAN
}

\author{
Oleh \\ Suranto Aw \\ FIS UNY \\ suranto@uny.ac.id
}

\section{Abstrak}

Fenomena pasar kerja pada era global sekarang ini, ditandai oleh semakin tingginya kompetisi untuk memperoleh kesempatan kerja. Dengan demikian lulusan sekolah kejuruan semakin dituntut untuk menguasai kompetensi yang unggul. Realitas tersebut perlu secara sungguh-sungguh diantisipasi dengan peningkatan mutu pendidikan. Dalam konteks inilah diselenggarakan uji kompetensi keahlian bagi para siswa, khususnya siswa Sekolah Menangah Kejuruan (SMK) yang secara sistematis dipersiapkan untuk menguasai keterampilan profesional.

\section{Kata kunci : Mutu, Kejuruan, Pasar Kerja, Kompetensi}

\section{Pendahuluan}

Dalam kehidupan yang penuh kompetisi seperti ini, tuntutan masyarakat terhadap kualitas pendidikan semakin tinggi, termasuk tuntutan terhadap kualitas pendidikan di sekolah kejuruan. Hal tersebut dikarenakan tugas sekolah kejuruan adalah membekali peserta didik dengan keterampilan profesional yang memadai untuk dapat menembus peluang kerja. Sekolah kejuruan dirancang untuk menyiapkan peserta didik atau lulusan yang siap memasuki dunia kerja dan mampu mengembangkan sikap profesional di bidang kejuruan.

Menurut Rupert Evans (Wardiman Djojonegoro,1998: 33) pendidikan kejuruan ialah bagian dari sistem pendidikan yang mempersiapkan seseorang agar lebih mampu bekerja pada satu bidang pekerjaan. Definisi ini mengandung pengertian bahwa setiap bidang studi merupakan program pendidikan kejuruan, sepanjang bidang studi tersebut dipelajari lebih mendalam dari pada bidang studi lainnya dan kedalaman itu dimaksudkan sebagai bekal menguasai kecakapan vokasional yang diperlukan di dunia kerja.

Lembaga pendidikan SMK merupakan salah satu pilar pembaharuan yang diharapkan dapat membawa perubahan bangsa ke arah yang lebih baik. Proses pendidikan yang berkualitas di SMK, diharapkan dapat mempersiapkan anak bangsa untuk menguasai kompetensi ilmu pengetahuan dan keterampilan sesuai dengan tuntutan global. Peran utama SMK adalah menghasilkan lulusan yang memiliki kualifikasi kompetensi kejuruan, dan dengan kompetensi itu diharapkan lulusannya segera dapat terserap di lapangan kerja, maupun mampu membuka lapangan kerja sendiri. Tujuan penyelenggaraan pendidikan di SMK (Depdiknas, 2007) sebagai berikut:

a. Menyiapkan peserta didik agar menjadi manusia produktif, mampu bekerja mandiri, mengisi lowongan pekerjaan yang ada di dunia usaha dan industri sebagai tenaga 
tingkat menengah sesuai dengan kompetensi dalam program keahlian yang dipilihnya.

b. Menyiapkan peserta didik agar mampu memilih karier, ulet, dan gigih dalam berkompetisi, beadaptasi di lingkungan kerja, dan mengembangkan sikap profesional dalam bidang keahlian yang diminatinya.

c. Membekali peserta didik dengan ilmu pengetahuan, teknologi, dan seni agar mampu mengembangkan diri di kemudian hari, baik secara mandiri maupun melalui jenjang pendidikan yang lebih tinggi.

d. Membekali peserta didik dengan kompetensi-kompetensi yang sesuai dengan program keahlian yang dipilih.

Lulusan pendidikan kejuruan diharapkan menjadi individu yang produktif, yang mampu bekerja menjadi tenaga kerja menengah dan/atau wiraswastawan yang memiliki kesiapan untuk menghadapi persaingan kerja. Kehadiran SMK sekarang ini semakin didambakan masyarakat, khususnya masyarakat yang berkecimpung langsung dalam dunia kerja. Dengan catatan, bahwa lulusan pendidikan kejuruan memang mempunyai kualifikasi sebagai (calon) tenaga kerja yang memiliki keterampilan vokasional tertentu sesuai dengan bidang keterampilannya. Permasalahannya adalah, sejauhmana sekolah kejuruan mampu mengakomodasi tuntutan dunia kerja untuk menyediaakan lulusan yang relevan dengan kebutuhan di lapangan. Secara teoritis, apabila terdapat kesepadanan antara permintaan dunia kerja dengan penyediaan tenaga kerja oleh sekolah, maka lulusan sekolah itu akan segera terserap di pasar kerja, dan pada giliran berikutnya dapat menekan tingginya angka pengangguran.

Fenomena menunjukkan bahwa tingkat pengangguran di Indonesia masih cukup tinggi. Data dari Badan Pusat Statistik (BPS), menunjukkan per Februari 2011 tingkat pengangguran terbuka mencapai $8,46 \%$ atau 9,43 juta orang, apabila dilihat dari tingkat pendidikannya didominasi oleh lulusan sekolah menengah (diambil pada tanggal 28 Desember 2011 dari http://onomist. wordpress. com/2011). Berdasarkan data tersebut, sebagian besar pengangguran di negeri ini didominasi oleh lulusan sekolah menengah, termasuk lulusan Sekolah Menengah Kejuruan (SMK).

Di samping terbatasnya lapangan kerja yang tersedia, kecenderungan terjadinya pengangguran tersebut juga dikarenakan oleh masih kurang memadainya kualitas sumber daya manusia lulusan lembaga pendidikan, yang ditandai oleh fenomena sebagian besar orang masih berbudaya sebagai penunggu dan pencari kerja, belum berbudaya sebagai pencipta lapangan kerja minimal untuk dirinya sendiri dan sesuai kemampuan dirinya. 


\section{Kualitas Pendidikan}

Kualitas pendidikan dipengaruhi banyak faktor, antara lain: siswa, pengelola sekolah (kepala sekolah, karyawan dan komite sekolah), lingkungan (masyarakat, orang tua, pengamat pendidikan), kualitas pembelajaran, kurikulum, dan sistem evaluasi (Edy Suhartoyo. 2005: 2). Hal senada juga dikemukakan oleh Djemari Mardapi (2003: 8) bahwa usaha peningkatan kualitas pendidikan dapat ditempuh melalui peningkatan kualitas pembelajaran dan kualitas sistem penilaian. Berdasarkan dua pendapat tersebut, tanpa mengurangi arti penting serta tanpa mengesampingkan faktor-faktor yang lain, faktor sistem evaluasi merupakan faktor yang sangat berperan dalam meningkatkan kualitas pendidikan, dan oleh karena itu kinerja dari berbagai program pendidikan perlu dievaluasi secara sistematis dan objektif.

Di kalangan masyarakat luas, kualitas pendidikan pada umumnya diukur melalui mutu lulusannya. Sekolah yang berkualitas adalah sekolah yang lulusannya memiliki pengetahuan, kompetensi, dan pribadi yang dapat diandalkan untuk bersaing. Oleh karena itu wajar apabila masyarakat menginginkan pemerintah melaksanakan suatu sistem pendidikan yang mampu membekali dan mengantarkan anak bangsa menjadi sumber daya manusia yang berkualitas sehingga mampu berpartisipasi secara aktif dalam berbagai lapangan kerja, dan dapat menekan angka pengangguran.

Melalui pendidikan yang berkualitas diharapkan dapat dihasilkan sumber daya manusia yang lebih berkualitas pula, yang mampu mengelola sumber daya alam secara efektif dan efisien. Dengan memiliki sumber daya manusia yang berkualitas, produktivitas negara akan meningkat, dan pada akhirnya diharapkan akan mampu meningkatkan daya saing dan kesejahteraan masyarakat.

Pendidikan harus mencerminkan proses memanusiakan manusia dalam arti mengaktualisasikan semua potensi yang dimilikinya menjadi kemampuan yang dapat dimanfaatkan dalam kehidupan sehari-hari di masyarakat luas. Muara dari suatu proses pendidikan, apakah itu pendidikan yang bersifat akademik ataupun pendidikan kejuruan adalah dunia kerja, baik sektor formal maupun sektor non formal. Salah satu jalur pendidikan formal yang menyiapkan lulusannya untuk memiliki keunggulan di dunia kerja, diantaranya melalui jalur pendidikan kejuruan.

Gambaran tentang kualitas lulusan pendidikan kejuruan yang disarikan Aisyah Jafar (2007: 3), bahwa : "Kualitas pendidikan kejuruan menerapkan ukuran ganda, yaitu kualitas menurut ukuran sekolah atau in-school success standards dan kualitas menurut ukuran masyarakat atau out-of school success standards". Kriteria pertama meliputi aspek keberhasilan peserta didik dalam memenuhi tuntutan kurikuler yang telah diorientasikan pada tuntutan dunia kerja, sedangkan kriteria kedua, meliputi keberhasilan peserta didik yang tertampilkan pada kemampuan unjuk kerja sesuai dengan standar kompetensi nasional ataupun internasional setelah mereka berada di lapangan kerja yang sebenarnya. 
Upaya untuk mencapai kualitas lulusan pendidikan kejuruan yang sesuai dengan tuntutan dunia kerja tersebut, didasari dengan kurikulum yang dirancang dan dikembangkan dengan prinsip kesesuaian dengan kebutuhan stakeholders. Kurikulum pendidikan kejuruan secara spesifik memiliki karakter yang mengarah kepada pembentukan kecakapan lulusan yang berkaitan dengan pelaksanaan tugas pekerjaan tertentu. Kecakapan tersebut telah diakomodasi dalam kurikulum SMK yang meliputi kelompok Normatif, Adaptif dan kelompok Produktif.

Pengembangan kurikulum merupakan suatu proses yang dimulai dari berpikir mengenai ide kurikulum sampai bagaimana pelaksanaannya di sekolah. Sudarwan Danim (2003: 14) mengungkapkan bahwa, aspek-aspek dalam prosedur pengembangan kurikulum terdiri atas empat dimensi yang saling berhubungan satu terhadap yang lain, yaitu : (1) kurikulum sebagai suatu ide atau konsepsi, (2) kurikulum sebagai suatu rencana tertulis, (3) kurikulum sebagai suatu kegiatan (proses) dan (4) kurikulum sebagai suatu hasil belajar.

Kurikulum yang diimplementasikan di SMK pada tahun 2010, khusus untuk kelompok produktif masih menggunakan kurikulum tahun 2004, sedangkan untuk kelompok normatif dan adaptif sudah menggunakan model pengelolaan Kurikulum Tingkat Satuan Pendidikan (KTSP) 2006. Pada tataran implementasi, kurikulum ini menuntut kreativitas guru di dalam memberikan pengalaman belajar yang dapat meningkatkan kompetensi peserta didik, karena betapapun baiknya kurikulum yang telah direncanakan pada akhirnya berhasil atau tidaknya sangat tergantung pada sentuhan aktivitas dan kreativitas guru sebagai ujung tombak implementasi suatu kurikulum.

Sementara itu dalam Permendiknas Nomor 23 Tahun 2006 tentang Standar Kompetensi Lulusan untuk Satuan Pendidikan Dasar dan Menengah, ditegaskan bahwa Pendidikan Menengah Kejuruan yang terdiri atas SMK/MAK bertujuan: meningkatkan kecerdasan, pengetahuan, kepribadian, akhlak mulia, serta keterampilan untuk hidup mandiri dan mengikuti pendidikan lebih lanjut sesuai dengan kejuruannya.

Sebagai salah satu alternatif solusi merealisasi fungsi SMK untuk dapat menghasilkan lulusan yang memiliki kompetensi unggul, pemerintah telah melaksanakan beberapa program yang sangat strategis, antara lain:

a. Mulai tahun 1994 pemerintah melaksanakan program "Link and Match", yang bertujuan untuk meningkatkan relevansi pendidikan kejuruan dengan tuntutan dunia kerja. Program ini diimplementasikan ke dalam format "Dual System Education" (DSE), yang mengkondisikan para siswa SMK mempelajari teori dan konsep di sekolah, dan mempraktikkannya di dunia kerja dan industri. Tujuan utama program DSE adalah mempersiapkan siswa sebaik mungkin agar dapat diterima di dunia kerja. DSE memberikan kesempatan berharga kepada siswa, 
yakni melalui kegiatan praktik di dunia kerja dan industri, mereka memperoleh pengalaman langsung dan orisinal tentang seluk beluk bekerja di dunia industri.

b. Mulai tahun 1999/2000 menyelenggarakan Evaluasi Tahap Akhir Nasional (Ebtanas) SMK dengan menerapkan sistem pengujian kompetensi atau "competency test" yang dilakukan untuk komponen Produktif dalam bentuk ujian praktik dan tertulis secara komprehensif - integratif. Sistem pengujian tersebut selanjutnya populer dengan nama Uji Kompetensi Produktif (UKP).

c. Istilah atau nama UKP, mulai tahun 2008/2009 diganti menjadi Uji Kompetensi Keahlian (UKK). Pada hakikatnya UKK adalah suatu proses evaluasi yang bertujuan mengumpulkan data untuk mengukur penguasaan kompetensi siswa. Kegiatan UKK terdiri dari dua kategori, yakni : (1) Uji Teori Kejuruan (UTK) dimaksudkan untuk menguji aspek teori-teori yang berbasis pada masing-masing program studi keahlian, nilai diakumulasikan dengan nilai raport; (2) Uji Praktik Kejuruan (UPK) ialah mata uji untuk aspek praktik program keahlian yang melibatkan pihak eksternal (Dunia Kerja dan Industri). Nilai UPK menjadi dasar penerbitan sertifikat kompetensi.

\section{Uji Kompetensi Keahlian (UKK)}

Pelaksanaan UKK selama ini ditandai oleh kurang optimalnya kolaborasi antara sekolah dengan dunia kerja. Idealnya, keterlibatan dunia kerja dimulai dari penyusunan standar kompetensi lulusan sesuai dengan tuntutan pasar kerja. Hal ini disebabkan, pihak yang paling mengetahui kompetensi yang dibutuhkan oleh pasar kerja ialah para praktisi di dunia kerja. Selanjutnya sekolah mengembangkan kurikulum mengacu kepada standar kompetensi lulusan tersebut. Standar kompetensi lulusan dijabarkan menjadi sejumlah standar kompetensi untuk setiap mata pelajaran. Standar kompetensi mata pelajaran selanjutnya dijabarkan menjadi sejumlah kompetensi dasar atau kompetensi minimal yang harus dicapai peserta didik. Kompetensi dasar ini dijadikan acuan untuk menetapkan materi pembelajaran dan sistem penilaian.

Giliran berikutnya, pihak eksternal (dunia kerja) terlibat dalam pengujian penguasaan kompetensi para peserta didik. Peserta didik yang dinyatakan kompeten memperoleh sertifikat yang ditandatangani pihak eksternal sebagai sebuah pengakuan pihak dunia kerja terhadap kompetensi lulusan. Masalah yang ada di lapangan, menunjukkan bahwa lulušan SMK masih banyak yang gagal memperoleh pekerjaan sesuai kualifikasi vokasi yang dimilikinya, meskipun sudah memegang sertifikat kompetensi yang sebenarnya merupakan bentuk pengakuan legal dari dunia kerja terhadap kompetensi siswa. Masih sering terjadi pihak asesor dari dunia kerja merasakan bahwa kompetensi yang diujikan lebih banyak mengacu pada kurikulum program keahlian, bukan pada kompetensi terkini yang dituntut dunia kerja dan industri. Sebaliknya ketika para guru dan siswa diminta komentarnya tentang kegiatan UKK, 
seringkali mereka mengeluh karena materi yang diujikan oleh asesor dari dunia kerja tidak sesuai dengan materi yang disampaikan dalam proses pembelajaran.

Pelibatan secara aktif unsur eksternal sebagai asessor maupun verifier diharapkan dapat mewujudkan suatu langkah strategis dalam menciptakan proses Quality Assurance (QA) dan Quality Control (QC) dalam sistem pengujian pada pendidikan menengah kejuruan. Dengan demikian, pelibatan unsur eksternal tersebut merupakan komitmen sekolah untuk dievaluasi oleh pihak eksternal guna mengkondisikan agar cakupan pembelajaran di SMK mengarah kepada kompetensi yang dituntut oleh dunia kerja. Selain itu, kegiatan UKK dengan melibatkan pihak eksternal, pada hakikatnya adalah sebuah pengakuan dari Du/Di terhadap kompetensi siswa SMK. Dalam hal ini, UKK merupakan sebuah kegiatan yang merupakan realisasi dari kebijakan pemerintah untuk meningkatkan mutu lulusan dan relevansi kompetensi peserta SMK dengan kompetensi yang dituntut oleh dunia kerja, terjadi dalam satuan pendidikan, dan melibatkan pihakpihak yang relevan.

Dalam Permendiknas Nomor 22 tahun 2006 tentang Standar Isi untuk Satuan Pendidikan Dasar dan Menengah, ditegaskan bahwa cakupan Kelompok mata pelajaran ilmu pengetahuan dan teknologi pada SMK/MAK dimaksudkan untuk menerapkan ilmu pengetahuan dan teknologi, membentuk kompetensi, kecakapan, dan kemandirian kerja.

Esensi kegiatan UKK adalah sebuah aktivitas evaluasi kompetensi siswa sebagai upaya peningkatan mutu lulusan yang berorientasi kebutuhan pasar kerja dan pengembangan sub-sistem dari kerangka sistem pengembangan sumber daya manusia berbasis kompetensi. Dalam Petunjuk Teknis UKK SMK Tahun Pelajaran 2008/2009 (Direktorat Pembinaan SMK: 2009: 1-2) ditegaskan bahwa hasil UKK bermanfaat untuk : a) memetakan mutu atau kualitas pendidikan kejuruan pada SMK; b) menghasilkan informasi capaian kompetensi siswa yang menjadi salah satu kriteria bagi pengambilan keputusan kelulusan siswa.

Manajemen UKK menunjukkan kenyataan bahwa uji kompetensi seharusnya dilakukan oleh sebuah lembaga atau asosiasi profesi yang independen dan profesional yang anggotanya terdiri atas pengguna lulusan (dunia kerja), para ahli dalam bidang yang diujikan, dan ahli evaluasi atau penilaian. Fakta di lapangan menunjukkan bahwa selama ini asosiasi profesi yang ada, belum mampu memberikan layanan yang memadai.

Mengenai tempat pelaksanaan uji kompetensi, selama ini pada umumnya peserta didik belum memungkinkan diuji di tempat kerja yaitu perusahaan atau perkantoran, namun dilaksanakan di sekolah yang diseting sebagai simulasi tempat kerja. Masalahnya adalah, bahwa situasi simulasi tempat kerja tersebut kadang-kadang belum mendekati situasi tempat kerja yang sesungguhnya. Situasi ini menyangkut aspek fisik maupun non fisik. Aspek fisik berupa ruang ujian sangat berbeda dengan 
karakteristik ruang kerja yang sesungguhnya. Aspek non fisik ialah lingkungan sosial yang diwarnai oleh adanya interaksi antarmanusia. Situasi interaksi sosial di sekolah, sangat berbeda dengan karakteristik di tempat kerja. Interaksi di sekolah didominasi oleh interaksi antarsiswa, dan antara siswa dengan guru. Interaksi di tempat kerja didominasi oleh interaksi antarkaryawan.

Produk dari kegiatan UKK adalah informasi mengenai capaian kompetensi siswa. Capaian kompetensi ini mendasarkan pada nilai hasil ujian, artinya siswa yang dinyatakan lulus dalam UKK disebut pula telah berhak menyandang predikat kompeten. Berdasarkan nilai UKK tersebut, bagi siswa yang lulus selanjutnya memperoleh pengakuan legal, yaitu berupa sertifikat kompetensi yang disyahkan oleh asesor eksternal dari dunia kerja atau asosiasi profesi. Mengenai esensi penyelenggaraan kegiatan UKK, dapat dibuat skema sebagaimana terdapat dalam Gambar berikut.

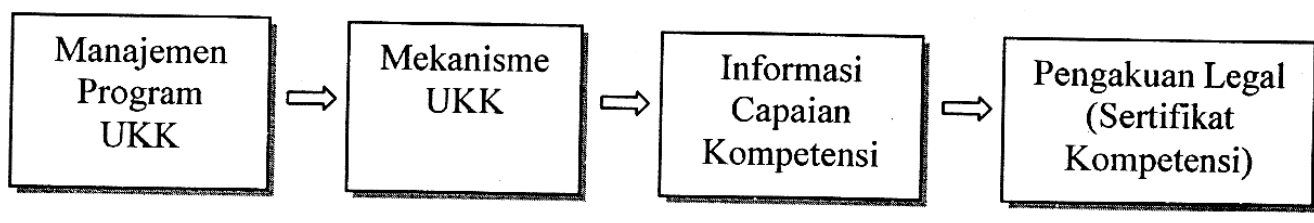

Gambar :

Esensi Kegiatan UKK

Melalui penyelenggaraan kegiatan UKK dapat diperoleh sekurangnya empat hal: (1) informasi apakah kompetensi yang diajarkan oleh sekolah sudáh sesuai dengan kompetensi yang diharapkan sebagaimana tertuang dalam Standar Kompetensi Lulusan (SKL) ; (2) masukan dari asesor untuk peningkatan sistem layanan sekolah; (3) informasi capaian kompetensi, dan (4) pengakuan legal.

Mengingat bahwa dalam penyelenggaraan UKK ini evaluasi atau penilaian kompetensi melibatkan pihak eksternal, maka dapat pula dimaknai sebagai sebuah rintisan pengembangan model evaluasi dan sertifikasi eksternal (industri). Jadi kegiatan UKK dimaksudkan sebagai pengenalan sistem evaluasi oleh pihak eksternal. Dengan adanya rintisan tersebut diharapkan akan diperoleh bentuk/model penyelenggaraan evaluasi dan sertifikasi yang sesuai dengan kebutuhan masyarakat dan industri.

Penyelenggaraan evaluasi dan sertifikasi yang mampu menghasilkan tamatan yang sesuai dengan standar yang ditetapkan oleh industri, tidak terlepas dari kesungguhan dari semua pihak yang terlibat (stakeholder). Di satu sisi pihak industri yang memiliki praktisi sudah menyediakan berbagai fasilitas, yaitu tempat praktik tenaga pelatih (trainer), dan tenaga penguji (asesor). Disisi lain pihak SMK diharapkan dapat memberikan kontribusi untuk pengadaan bahan, dan tidak menutup kemungkinan menyiapkan fasilitas dalam pelaksanaan pengujian. Mengingat SMK sebagai sekolah kejuruan yang berusaha mempersiapkan lulusannya memasuki dunia kerja, maka 
program UKK sangat strategis maknanya. Penilaian atau uji kompetensi adalah penilaian periodik yang secara khusus dijadwalkan oleh sekolah sebagai bagian tidak terpisahkan dari jadwal kegiatan akademiknya. Kegiatan uji kompetensi dapat digunakan untuk: (a) memantau dan mengendalikan kualitas proses dan hasil pembelajaran; (b) sertifikasi atau pemberian sertifikat; (c) menentukan ketercapaian penguasaan tujuan pembelajaran sesuai dengan Standar Kompetensi Lulusan (SKL) untuk jenjang SMK; (d) peningkatan mutu pendidikan berbasis pasar kerja. Dalam Permendiknas Nomor 22 Tahun 2006 (Permendiknas, 2006) disebutkan bahwa SKL adalah kualifikasi kemampuan lulusan yang mencakup sikap, pengetahuan, dan keterampilan; SKL meliputi kompetensi untuk seluruh mata pelajaran atau seluruh kelompok mata pelajaran.

Prosedur ujian dalam rangka UKK dilakukan melalui tes lisan, tes tertulis, tugas, kuis, project work, observasi, tes perbuatan, wawancara, simulasi, dan portofolio. Dengan demikian UKK merupakan sistem evaluasi berbasis kompetensi terhadap rangkaian pelaksanaan implementasi kurikulum SMK yang dikemas dengan pendekatan kurikulum berbasis kompetensi (competeny based curriculum) berbasis luas dan mendasar (broad based curriculum) dan pengembangan kecakapan hidup (life skills).

Pelaksanaan penilaian kemajuan dan hasil belajar, diarahkan untuk mengukur dan menilai performance peserta didik, meliputi aspek pengetahuan, keterampilan dan sikap, baik secara langsung pada saat melakukan kegiatan belajar, maupun melalui bukti hasil belajar (learning evidence) sesuai dengan kriteria kinerja (performance criteria) yang diorganisasikan dalam bentuk portofolio.

Kegiatan UKK dapat dikategorikan sebagai kegiatan evaluasi dengan sasaran yang bersifat mikro, yakni evaluasi untuk mengukur penguasaan kompetensi siswa pada komponen produktif (keahlian) meliputi aspek kognitif, psikomotorik, dan afektif sesuai dengan bidang dan program keahlian, serta untuk meningkatkan relevansi kecakapan yang diajarkan oleh sekolah dengan kompetensi yang diharapkan dunia kerja dan industri.

Berdasarkan wawancara dengan beberapa orang penguji (asesor) dari pihak eksternal (dunia kerja) diperoleh informasi bahwa salah satu masalah dalam penyelenggaraan UKK selama ini, masih sering terjadi kompetensi yang diujikan lebih banyak mengacu pada kurikulum program keahlian, bukan pada kompetensi terkini yang dituntut dunia kerja dan industri. Hal ini sejalan dengan hasil wawancara dengan beberapa orang lulusan, yang mengatakan bahwa ada tuntutan kompetensi pada beberapa jenis pekerjaan di industri dan perkantoran tidak sinkron dengan kompetensi yang dipelajari dan diujikan di sekolah.

Sebaliknya ketika para guru dan siswa diminta komentarnya tentang kegiatan UKK, seringkali mereka mengeluh karena materi yang diujikan oleh asesor dari Du/Di 
tidak sesuai dengan materi yang disampaikan dalam proses pembelajaran. Hal ini mengindikasikan bahwa kolaborasi sinergis antara sekolah dengan pengguna lulusan yaitu dunia kerja dan industri masih perlu ditingkatkan. Idealnya, keterlibatan Du/Di dimulai dari penyusunan standar kompetensi keahlian sesuai dengan tuntutan pasar kerja. Selanjutnya sekolah menyusun kurikulum sesuai dengan standar kompetensi keahlian tersebut. Pada giliran berikutnya, pihak eksternal (Du/Di) terlibat dalam pengujian penguasaan kompetensi para siswa. Siswa yang dinyatakan kompeten memperoleh sertifikat yang ditandatangani pihak eksternal sebagai sebuah pengakuan pihak Du/Di terhadap kompetensi lulusan. Diharapkan dengan sertifikat kompetensi yang dimilikinya itu, akan memudahkan lulusan dalam berkompetisi di dunia kerja.

Dari sisi materi soal ujian, kesesuaian arah substansi isi UKK dengan SKL nampaknya perlu dievaluasi. Hal ini disebabkan, standar kompetensi merupakan acuan bagi sekolah untuk menyusun kurikulum. Selanjutnya kurikulum diimplementasikan dalam proses pembelajaran. Untuk mengetahui keberhasilan pembelajaran, dilakukan uji kompetensi. Dengan demikian, materi uji kompetensi juga harus sesuai dengan cakupan SKL serta materi pembelajaran.

\section{Kesimpulan}

Kompetensi merupakan kata kunci dari proses pendidikan terutama untuk sekolah kejuruan. Untuk dapat menembus peluang kerja, lulusan sekolah kejuruan diharapkan memiliki kompetensi yang memadai. Kompetensi dapat. dilihat dari dua aspek yakni sebagai atribut individual dan sebagai hasil pembelajaran. Dari aspek atribut individual, kompetensi dapat diartikan sebagai pengetahuan, keterampilan dan kemampuan seseorang (individu) yang dapat menghasilkan unjuk kerja. Dari aspek hasil pembelajaran, kompetensi dapat diartikan sebagai sejauhmana seseorang telah menguasai materi pembelajaran yang diimplementasikan dalam unjuk kerja sesuai dengan kebutuhan di lapangan kerja.

Melalui kegiatan UKK yang melibatkan asesor eksternal dari dunia kerja dan industri, dapat dilakukan evaluasi penilaian apakah kompetensi siswa yang diperoleh melalui pembelajaran di sekolah telah sesuai dengan yang dituntut oleh dunia kerja. Keterlibatan pihak eksternal dalam UKK juga dapat dipahami sebagai sebuah bentuk sikap keterbukaan dan antisipasi pihak sekolah terhadap terjadinya perubahan yang cepat di dunia kerja.- 


\section{Daftar Pustaka}

Aisyah Jafar, dkk. (2007). Materi uji kompetensi 2008. Diambil pada tanggal 13 Agustus 2008 dari http://209.85.175.104/search?q=cache:GfP vhf6W8YJ:download. ditpsmk.net I t4mu/01.MATERI UJI KOMPETENSI 2008.

Departemen Pendidikan Nasional. (2007). Spektrum bidang dan program keahlian sekolah menengah kejuruan. Jakarta: Direktorat Pembinaan SMK

Direktorat Pembinaan SMK. (2008). Surat Edaran Direktorat Jenderal Manajemen Pendidikan Dasar dan Menengah Nomor: 351/C.C5/MN/2007 tentang Uji Kompetensi Keahlian Kejuruan. Diambil tanggal 22 Mei 2008 dari http://209.85.175.104/ ditpsmk.net/ 2008.

Djemari Mardapi (Januari 2003). Kurikulum 2004 dan optimalisasi sistem evaluasi pendidikan di sekolah. Makalah disajikan dalam Seminar Nasional Kurikulum 2004 Berbasis Kompetensi, di Universitas Ahmad Dahlan Yogyakarta

Edy Suhartoyo (November 2005). Pengalaman peningkatan mutu pendidikan melalui pengembangan budaya sekolah di SMAN 1 Kasihan Bantul. Makalah disajikan dalam Seminar Nasional Peningkatan Mutu Pendidikan Melalui Pengembangan Budaya Sekolah, di Universitas Negeri Yogyakarta.

Wardiman Djojonegoro. (1998). Pengembangan SDM melalui SMK. Jakarta: PT Jayakarta Agung Offset.

\section{BIODATA}

Suranto Aw, MPd. MSi. menyelesaikan pendidikan S1 IImu Komunikasi di Fisipol UGM tahun 1986. Tahun 1996 lulus S2 Magister Penelitian dan Evaluasi Pendidikan IKIP Yogyakarta. Tahun 2000 lulus S2 Magister IImu Sosial BKU IImu Komunikasi Universitas Padjadjaran. Sekarang menduduki jabatan Lektor Kepala pada Prodi Pendidikan Administrasi Perkantoran Fakultas Ilmu Sosial Universitas Negeri Yogyakarta. 